これまでの民族（国民性についての論説は科学との へだたりの大きいものであった。たと弯ば，戦前の国定 教科書（尋常小学国語読本・卷12）には，「我が国が世: 界無比の国体を有し，三千年の光輝市る歴史を展開し来 って, 今や世界石大国の一比数へられるやらになったの は主として我々国民にそれだけすぐれた素質もあったか らである。君と親とに真心を捧げ尽くして仕える忠孝の 孫が世界に冠たることは，今更いふまでもない，忠孝 は先に我が国民性の根本をなするの」であるという説明 が指載されていた。来た「国民性十論」の芳賀矢一は，

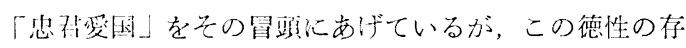
估竍明にあたって，古今のいわゆる愛国歌を羅列して

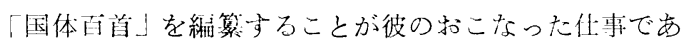
った。つまり，民族（国民）性とは，ここでは，国家主 義, 軍国主義が国民に「期待」した微性にほかならなか った。

（3）民族（国民）性の科学的研究とは何か。それはな によりも，「民族」といら概忿が社会科学のそれである ことを理解することから出発しなければならない，民族 とは，「言語」「地域」「経済生活」「文化の共通性の らちにあらわれる心理状態」とう四つの特微を共通にも った人々の堅固な歴史的構成体であると定義される。

\section{III 臨床}

オーガナイザー 佐治 守夫(東京大学)

座長古沢頼雄(日本女子大学)

話題提供者 佐々木 正美(秩父学園)

内堀照夫(中野区立北原小学校) 茂木 俊彦(東京大学)

村瀬 孝 雄(国立精神衛生研究所)

このシンポジウムに於いては, 諭題にある臨床と教育 各々の美異を規定していくのではない，われわれが子ど もにかかわるという事の中で，われわれの方から視野を 定めた上で子どもの生活している状況を見，そこに子ど ๖の行動の普遍性を見出そらとし, 教育（状沉）。臨床

(状況)という名をつけているきらいがなかったである らかといら反省を出発点にしてみたいと考光る。予どあ にとっては，そのいずれに㨟いても発達していくといら こと，しかも，それが現実の生活状況の中でなし逐げら れていることには変りないのではないだろらか.

そこで，大人が子どもにかかわるといらことはどのよ うな意味をもちうるのか，そのとき，大人はどのような
(スターリン「マルクス主義と民族問題」参照) そして ことに，「経済生活」の共通性は，資本主我の発眼がそ の封建的細分，割拠状態を否定したことによって獲得さ れたものであるから，歴史に㧍ける民族という概念の登 場が資本主義社会のそれと歩調をそろえたものだといら ことになる。近代国家は，資本主義の発展と民族的統一 を前提条件と民族国家としての日己形成を志淌した。

ところで，「対立物の統一と闘争の法則」とよばれる わのが，弁証法のもつとも基本的な法則である。資本主

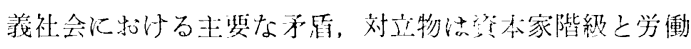

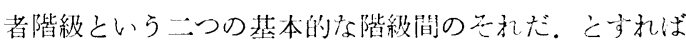
民族の概念が上記のように理解される以上，民族(国民) 性の研究は，な汇よりも，この主要な対立物の提案を不 可避とするもの，といらことになる．

したがって, 階級の問題を唅象して, ある民族, 国瓦 の一般的なハーーソナリティの特徵を, 統計学的な最频数 に該当するものとしてもとめようとする收近のいわゆる modal personality の理論には反対である.

（注）私はスターリン論文における「文化の其涌性の らちにあらわれる心理状態」といら項目には検対 が必要であると考えている」。

\section{と教 育}

わくぐみ西るいは態度によってかかわり，何を自分の中 に問い直していくことが必要であるのか，について子ど もをとりをく㥞々の視点から限られた時閒の中で考え合 っていきたいとの前置きで以下の発表がなされた。

(古沢 頼雄)

\section{発表 要 旨}

a. 传: 朴 泎美

一人の児童精神科突として, 中枢神経系に巫度の障害 をもった児童の収容施設で働くかたわら，東京拉よびそ の近県の地域社会へ, 同じような障害巟の医潦や教育に 参加するために出かける機会が多いが，そこで㾋感する ことは，障害児の両親たちの絶望的な深い悲しみと代父 と苛らだちである。そして，障害胃にかかわり合ってい るわれわれセラピストや教育やケースワークを担当して いる者たちも, やがて, 同じょうな重苦しい焦燥感に生 しつぶされそうになっている。障害奣の周固にいる者 がかが国の現在の社会に対していだいている不信感は

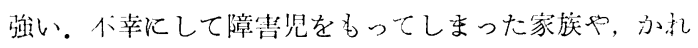


教育心理学年報第 12 集

らの医療や教育にかかわりをもつことになった人たち が，それぞれの責任のように感じながら，かれら障害児 のために，社会の中の居場所を探し当てなければならな いのである。家族の人たちは，障害児を連れて，病院や 相談のための機関を自らの判断であちこちかけめぐり, 八力ふさがりの地域社会の中で, 困惑した原陑や相談員 たらの表情に失望している。

私が, 児童精神医学, 特に地域精神医療の勉克強のため に1970年夏から1年余り滞在したカナダのバンクーバー 市では，このよらな不幸な雲用父はなかった。障茜児の 家族も教師もセラピストも，かれらの住を地域社会への 信頼にあふれていた。家庭, 学校, 病院のほか, 各種の 地域機関が，有機的に連結し合った地域社会は，個々の 児童の教育や原療などの閣定を, 社会の側から積極的に 解決していく姿勢を示していた.

そういら地域社会を支える原動力は，何よりもまず， あらゆる人々がそれぞれの個性や能力を超えて, 等しく 認められ，認め合えるとい生う活習慣であろう。当地で 私が学んだ病院の児童精神科を訪れる学童の大半は, そ の慢性で重症の障害のために, 学校では留年といら形で 新しく編成されたクラスで教育を受けたり受けよらとし ていたりした。またかれらの両親や同胞が，12年間の義 務教育のらちに， $1 〜 2$ 年の留年をしていることも稀で はなかった，わが国のように知的側面のみを桠端に優先 させて考える教育システムの中では, 学徸に対して, 留 年の与える社会的, 心理的影㗽の大きさ想像にあまり あるため, 一般にはいわゆる少等児に対する具の阮虑は あまりなされないまま, 絬果としてとの知的教育も知的 優良者に対してなされているにすぎないことが多い．

この知的競争に象徵される過当競争社会の中で，われ われは各種のハンディキャップをもった人たらに対し て, 真の同情や理解をいつどこで学び得るのか, 各人が あらゆる個仯や能力を超えて, 等しく存在し得ることの 認識を，いつどこで与えられるのか，私は知らない、そ らいら人々の構成する地域社公に, いわゆる弱者や障害 考を受け入れる精神的な準備のないことは, 古しろ当然 であろう。

心身に重いハンディキャップをもつ览童と, 日常接す ることの多い...人の医師として，大きな期待を寄せたい 地域社会ぐるみの治療教育の方法について，どうすれば 大きな希望が持てるか，討論し合いたい。

\section{b.}

内堀 照夫

小学校教員として見場で感じていることに2・3ふれ てみる。
(1)子どもたちの成長をみていくと，ひとりひとりが個 性をもっている故に, これが○学年, ○才だなどといら 標準的なものはみつからないように考えている。そして これまでの経験では, 教育心理とか児童心理ということ を前提に置いた，あるいは，それらにもとついた教青方 法といらものは生きてこなかったように思われ, 子ども ひとりひとりにあった何かがもっと用意されなければな らないと考えている.

(2)このことは, いわゆる普通学級の中で自閉症之いわ れる子どもを取扱っていく場合にもまったく等しく当て はまる。

(3)子どもの能力ということよりももっと人間の尊版と いったところから発する関倸のありおが市を゙の成長を 大きく支えていくよらに考えられる。

c.

茂木 俊彦

障害罗の発達理論の立場から，「臨休と教育」の問題 にせまってみたい。

1）一般に，人間の発羊過程には，いわゆる質的転換 期がいつもあることが，たしかめられてきている．障害 がある場合は，この転換期を越えにくく，障害をもたな い人の場合よりもその矛盾を払大しやすい，広義の教育 場面でみらられ種々の「問題行動」も，それらの発達論 的把握を基礎として再吟味し，そのことによってわれわ れのはたらきかけの体系をよりよいもの汇変えていくこ とができるのではないか.

2）いわゆる「問題行動」といわれるものに, 対症療 法的にアプローチしても, 真の問題解決にならないこと はよく指摘される.

じっさい，「子どもが問題行動を起したとさ，われわ れの課題は，……な゙かれがそのような行動を必要とし たのか，その法でどんな葛滕をかれは解決しょらとし たのか, どらしたらより正しい方法で解決するようにか れを援助することができるのか，と考えることである」

\section{(L. Kanner)}

また他力では，あらわれる「問題行動」の種類や内容 が，発達の質的転换期とのかかわりで変化することがし られてきている。

たとえば，障害をもつ子ももたない子も，発達年令 1 才半前後で, 種々の「問題行動」が指摘されるが, これ らは2才半〜3才で殆ど消失するといら，1才半前後と いら時期は，発達的には，対応した反対方向のふたつの 行動を、ひとつの行動単位としてまとめあげ，ひとつの 絬合点をつくりながら外界にはたらきかける段階と考え られるが，障害があったり，かれをとりまく諸条件が不 
十分にしか整えられていないとこの転換期に问から時 期の行動様式がパーン化しやすい.

それは「発洤要求」の不正常なあらわれともいえるわ けで、ここを正しくとらえた教育その他の先践密度の高 度化が必要である。

3）そのさい，われわれは，単に当該乔を「心理的解 放を肬さという「治療場面」に拉くというのではなく 発達乵断を，当該巟のみならず，か机をとりまく子ども 集団，指導者集団をも対象として行ない，糟極的な教育 的指導を展開していくことが重要ではないか.

な志，もちろん，「問題行動」の発生・固苜化のx力 ニズムを，人間関係一蓇児や教育の罟々の技術を含む一 のみから考党るのでは不十分なことはいらまでもない. 子どもの発達，これにかかわる笑践悹，その根底に拈い て規定与る客観的一物質的諎条件の分析もまた不可決で ある。

\section{d.}

村瀬 孝雄

臨休心理学, 教育心理学といっても人によってもつイ メージに開きがあるう。私は, 私が学んだ瀶床心理学,

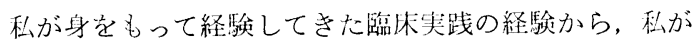
今の日本の教育心理学と考え，また煘じとっているもの について山頃思い，考えていることを述べてみたい。

私がかねがね不思議におもい，㭙には恐しくさえ感じ ていることは，教育心理学を専攻している人迋の多くは 子どもや学生を「教育」するといら人類の基本的営又に ついて，本気で考えたり，悩んだりしたことがないので はあるまいか，ということである。子どもを，どんな人 間に育てようとするのか、それにはどんな意味があるの か，それを本当汇達成するにはどうしたらよいのか．教 育といらもっとも人間的価值の高い行為について, 何ら 根本的な考察もなく，深い会得もないところで，ただ末 梢的な技術論や断片的な知識の集積に堂々とこれつとめ てきたのが大部分の教育心理学者であったといっては言 渦ぎだろらか？

大休，医療経験をもたずに臨床医学を研究したり，垁 験についての透徾した理解をもつことなしに物理学を㞧 攻することはナンセンスである、しかるに教育心理学者 が自らの真剣な教育実践をその教亩心理学の土台にすえ ている例は殆どきかない，優れた教育止践の記録訬く ないが，そのいずれもが教阬の人柄と知恵と努力の成果 であって, 教育心理学を応用してそのよらな成果をあけ゚ た例は寡聞にして知らない。教育心理学にそのよらな力 がないなら，現場の偐れた実践を虚心に研究し，そこか ら新しい教育心理学をつくっていこうとするのが真に教
育と結びついた心理学であるはず，と私などは思うが，

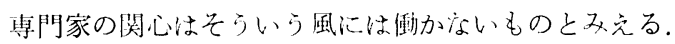
われわれ臨床家からみると, 牛徒の可能性を公く深く青

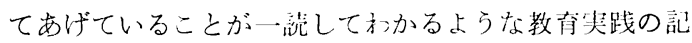
䟿には, 臨林心理学的尖践之極めて相通ずるものがあり 非常に教えられるところも多い、ひょっとすると，瀶休 心理学々教青丰践との間の距離の方が, 教育心理学と教 有奏践との間の距離に比べて，ずっと短いので梳ないか， 少くとも日本では。

しかし考えてみると教育心理学がこうなってきたこと について教育心理学だけを責めるのは酷かも知れない. アメリカの素年心理学のあるかなり古い文献を読んで驚 いたのはその書面にまとめられた調査研究は当時アメリ カの中学校のカリキュラムを大きく変える必要が指摘さ れていて，このカリ丰ラム作成の参考にする基礎資料 として用いるべく当㭙の中学生の人格や能力について行 われた科学的研究であったのである。わが国の教育は， 明治以来, 現在もなお，根本的には政治が優先しており 科学的知見にもとづてて教育を考えるなどという習慣も ゆとりも無いのである。

現在私が行っている日本の中学, 高校生の人格発達に ついての研究や幾つかの阙係深い調查などの結果からら かがえることは，日本の中，高校仅とくに界子の $1 / 4$ か ら1/3は人格の望ましい発趡にとって著しい障踳となる

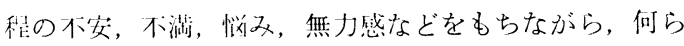
根本的援助，改善の手段は講じられていないという事奏 で西る，尘徒達が孤立化，蹯外化の方向をたどり，次第 に無気力になり，物質による一時的快感や父晴らしに逃 げつつあることは多くの教師が経騟上，はっきりと指摘 するところである。

教育心理学はこの事然をどうらけとめているであろう か.

日本の教育状況が極めて困難な局面を迎えつつあると きに，教有心理学がこれに無関心であるとしたら，その 病理は恐るべき状態にあるといわねばならない・

\section{討 論の 概 要}

討論時间として残されたのは20分ばかりであったため 1・2の発言がなされたに留まった。ここで、意見とし て記されて提出されたものをも若干ここでは揭戴してお $<$.

野村（学去大）：教青心理学が教育央践にどうかかわ るかについて，いままでの教育心理学はその主観性をど のように客観的に意味づけるかを示すのをその課題とと 
らえて来た。そこでは教骨实践を支える個人的，社会的 条件に既成の方法論でどのようにかかわっていけるかが 問題となっていたのであるが，それを支える条件をどう 作っていったらよいかについてとりあげることは出来な かったのではないだろらか。

茂木（東京人）：既成のもので使えるかどらかとい 問題のたて方をまず检討しなければならないであろら。 その中で明らかにされて来た䒠定実践との結び付きの 中でも5一度, 分析・再檴成していく課題があるのでは ないか，その中で事车は新しい意味をもってくる可能性 があろら。その法論の確立が急がれねばならないであ ろう。物的条件・人的条件を考虑に入れ，従来のではは 又出るかもしれない条件を考慮に入れることによって， とらえな扎しが可能となろう。

岡(聖心女子大): 教育心理学々臨朱心理学についての 枠づけそれ自体があまりにも観念的で一つの角度からの み誇張されている。そのよらな傾问があるのはいなめな いが今回の学会のいろいろな発表をきいていると（尤も 発達の力を主としてきいたが）新しい方法からみていく 研究者がかなりると思っている。

高憍（愛育研究所）：人間（個人）の尊重といら事が 個人的要求の充足という経過の中ばかりで䦌われ，社会 他人とのかかわりがなかったとしたら，それはいつまで も有機的情緒の満足というような低い段階汇止める事に はなりはしないか？それを価值ありとみるのは教育者 や治療者の幻想といえるのではないか？ 洒值ありとす るならばその拠り所は?

帆足（川村短大）：社会事情に是をふまえた教育心理 学が研究されねばならないいとうことは真実で㐫る。日 本と欧米とで社全事情が違ふので，欧米の引用だけの学 見ではピッタリしないことを感ずる。欧米の引用のみに 終っているのか，そうでないのかの証拠を知るためにも また, 教育心理学本来のあるべき姿からいっても, 教育 心理学の体系沈も哲学 (philosophy) がなければならな い。たと竞ば，高橋氏が欲求を大切にしても社会に通用 しないといわれるのは日本の社会に拈ける央感だと思 う。ただし私は日本の社全のいき方を暫定するおけでは ないのたが，日本の社:会と欧米の社会との大きな美をこ の頃感じどうにかしなければと，悩んでいるところであ 子.

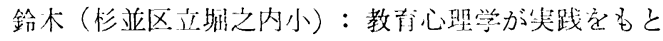
にすすめられなければならないとすれば「理論と垁践は 違う」などといらことはありえないだろう。しかし夷際 に現状がそうであるならば，学会として集団的に刢議し
て，どらあらねばならないかを研究者も実践者も真剣に 考光, 具体的に行動を抗こすことではないだろらか.た と壳ば，砳究者白身の興味関心も大切にされなければな らないが，もっとわが身のおかれている立場を認識して 尖践と密着した研究活動を任務としていかねばならない のではないか。私自身は, 現在自閉症といわれる子ども の教育実践にとりくんでいますが 従来いわれているマ ンッーマン方式に対して集団として，あるいは集団的に 教有することの意義を強調したい。その前提として，い かに教師集団が集団として重要な役割りを果すか，いや といらほど知らされた，このことから学会としても学会 活動を, 砂究者の研究活動をいかにすべきか, 集団的に 考える必要があると思うが, 教育心理選択でなくい内容 を改革すべき

大野（都立大）：保健所の三才児健診にたずさわっ て, 子供の䦗題行動汇社会的要因が非常に大きく関係し ていることを痛感しています。従って我々は只, 治療に たずさわるだけでなく，そういうここで気ついた問題点 を社会に訴える等の働きかけも必要ではなからうかと考 えます。それと同時他人の問題性を発見し，その援助 にたずさわろうとする Clinical psychologist といらも のは不必要な扩せっかいやきなのかという自己批判のよ らなものを感じます，短時間ですので充分に白分の気持 を表現しきれませんが........

津守(扣茶の水女子大)：1．現状の教育ととりくもら としている人々があることを知って心強く思った２， 従来の心理学の訓練をすてなければ新しいものは生まれ てこないと思う。 3 , 行動を客観的, 実炋的, 物質的に みてカテゴライズする考えうではだめである、精神面す なわち行動の背後にある世界をみる訓練を必要とする。

山本 (秩父学園)：社会との関わりの殆どない所で討 論が進行していた。

子ぞもの示す行動の中にはその子供の発達要求, 欲求 等が含まれていると思う。現場において「問題行動」と 言う場合往々にして，その子そのもののみに目がむけら れ，その子供をとりまいている情況を捨象した中でとり 上げられることが多い。子どもの側に立った時「問題行 動」とレッテルをはることは果して言えるのだろうか. 茂术氏が「閑題行動」と言われる時どこに問題行動と咅 わしめる基準を扎いているのか一社会との関倸で

福田（神开大）：臨床への道を迷いつつ志している学 生です。権利としての教育の機会を奪われてしまってい る者のけ已串現の方法をさぐりたいと思っていますの で、シンポジウムを実に興味深くききました。私が今学 
柴のかたわら子どもに接するねで考えていることは，栐 々ある問題の原因が福祉行政の貧しさにあることが明瞭 な場合でも，関係者はその仕小のはげしさのために，た ずさわっている仕事や治療でFがいっぱいであり, 所属 する医局以の精神衛生の改善すらできないことです。な んとかとれを+ークル活動なり，小さな市民運動なりに 広げることができたらいいと思うのですが，実際に働き つつそうしたことをやっていらっしゃる先生方の括を らかがいたいと想います。素朴な感想です。

このシンポジウムは, 第13回総会に执けるシンホジウ

\section{IV シンボルと集団}

オーガナイザ 泉

座長同上

話題提供者

a 政治的社会化の立場から

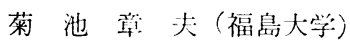

b シンボリック・インターラクショニズムの立 場加 5

折橋徹 彦 (闺東学院大学)

c 栠団論の立場から

古畑 和 孝(国際キリスト教大学)

d 䊑神医学の立場から

小見山実（電機通信大学）

島田：シンボルとかサインとか言われるものは，言語 化されるものもあり,されないものもあるが, シンボル 快とくに，社会生活の中で，われわれの共通体験をま之 めあげる意味機能を果たしている。シンボルは・主体を 導いてその対象を心に描くようにさせる。そしてシンボ ルが直接に意味するものは，サインのように，刘象その ものではなく，刘象に関する意味とか象徴である。

シンボルと集団といらテーマの場合には，身団の全体 性にかかわる社会的機能が䦌題にされる。したがって， こういったシンボルは, 政治社会や宗教社会でつくり出 され，㙨能する場合が多い。たとえば，政治的シンボル としては，国とか民族，神話，イデオロギー，英雄とい ったものから, 日本では, 富土, 桜といった具体的なも のまで，いろいろあげられる。ところで, シンボルは， 体験がシンボルによって客観化されたときから，オリジ ナルな体験が意味を失っていって，単なる日常的なサイ ンに変わってしまらといら遇程が胃られる。シンボル操

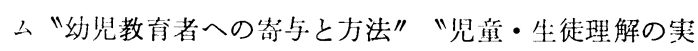
践方法”で問題となったことをやや角度をかえてより現 実的に論じていこうとしたものであるといえようが，い ろいろな制約からして論点の定まらぬまま終えてしまっ たといえよう、時間をかけた丹念な論議がなければ充実 した成果は得られないだろう。その意味でこのような機 会を足がかりになお深め合ら機会が重ねられればと思 う. (古沢 頼雄)

作は、このようなシンボルからサインへの変質を防ぎ， あるいはこのような過程を逆転させて, シンボル特性を 再生させるといら機能をもっている。しかし, シンボル 操作によって，意味を回復させようとするはたらきには 限界があって，それが果たせなかった場合には，シンボ ルは本来のはたらきを坐っていくのである。現代のよう な価值体系の変化がはなはだしい侍代には，このような シンボルのはならきが衰え, 失われる現象がみられる。

教育も，一種のシンボル操作を含さが，このよらな情況 は, 現代, どのよらにとらえられるであろうか。

折憍：現代の社会で生活する人間は，心理的にはいつ も動摇している。動摇が表情や動作に表われやすい人も いれば，まり外に裴われない人もいる。やたらに他人を 不安に侔れるような言動をする人たちを見かける。そう いら場合には，他人を不安がらせているその当人白身の 中に激しい情緒的不安定の原因があることが多い，しか 乙, 心理的安定とか不安定の問題は, 企く個人の心理生: 活の中に閉じこめてしまらことができるようなるのでは ない，一人の人間が生きている社会のしくみの中で，彼 がそのしくみにどのよらに組み込まれているか, 彼がど のような状況に执かれているかが，彼の心理的な状態に 反映されている。

学眭紛争もステータスの高い大学とステータスの低い とみなされる大学とでは, その紛争の起る原因・契機と いったようなものが違うようだ。わたくしが関係してい る大学でも，智が然えたことが紛争のキッカケになった が大学の教師は何もできないという虚脱感をもちながら も, 同空生のはたらきや種々の経過を経て, 近代化路線 に沿う経営参加などを含めた改革が出された。しかし， その際リーダーシッブをとった教授会の人びとがまとま 
points at issue: how educational psychology views social psychology. Prof. Asami offered a general outlook on psychology of learning in conection with educational psychology. Finally, cinical problems concerning educational psychology were offered and discussed by Prof. Moriwaki.

\title{
SYMPOSIUM II
}

\section{Dialectics as a Methodology in Educational Psychology}

\author{
Organizer: Kojiro Naito (Hiroshima-denki-University) \\ Chairman: Bantaro Kido (Hokuseigakuen University) \\ Speakers: Kojiro Naito (Hiroshima-denki University) \\ Naoki Nishihira (Yamanashi University) \\ Kohei Matsumura (Ochanomizu University) \\ Masatoshi Sera (Chuō University)
}

Applicability of dialectics to educational psychology had also been discussed at the general symposium of the Annual Convention of Japanese Educational Psychology in 1955 and 1967.

In the present age of educational chaos, is seemed to be significant to reconsider this theme as an up-to-date matter for the purpose of reorganizing and settling the educational disputes.

First speaker Prof. K. Naito offered a present-day problem of dialectic epistemo$\log y$ and its application to educational psychology especially in terms of mathematics and fine arts. Prof. N. Nishihira also discussed the application of dialectic theories to adolescent and educational psychology. Dialectics concerning human relations by Prof. K. Matsumura and research on the racial problem from dialectic point of views by Prof. M. Sera were presented.

\section{SYMPOSIUM III}

\section{Clinical Psychology and Education}

\author{
Organizer: Morio Saji (Universizy of Tokyo) \\ Chairman: Yorio Kosawa (Nihon-Joshi University) \\ Speakers: Toshihiko Mogi (University of Tokyo) \\ Teruo Uchibori (Kitahara elementary school) \\ Takao Murase (National Institute of Mental Health)
}

What do we think about clinical problems in education? What is the meaning of these clinical problems in the process of child development? What is the most crucial problem that we psychologists have to confront with concerning clinical psychology 
and education?

From these points of views, four speakers from different fields offeresd their practical problems stemmed from their own experience.

\title{
SYMPOSIUM IV \\ Symbol aud Group
}

\author{
Organizer and Chairman: Kazuo Shimada (Seishin-Joshi University) \\ Speakers: Akio Kikuchi (Fukushima University) \\ Tetsuhiko Orihashi (Kanto-gakuin University) \\ Kazutaka Furuhata (International Christan University) \\ Minoru Komiyama (Denki-tsūshin University)
}

In order to explore a point of contact between educational psychology and social psychological problems, Symposium IV was held under the title of "Symbol and Group".

Information exchange in psychology with the cooperative participation of four speakers from different field was expected. Prof. A. Kikuchi discussed problems of political socialization. Problems on symbolic interactionism by Prof. T. Orihashi; on group theories by Prof. K. Furuhata : on psychiatric point of view by Prof. M. Komiyama were presented at this session.

\section{SYMPOSIUM V}

\section{A Contribution of Educational Psychology to Instructional Methodology}

\author{
Organizer and Chirman: Hiroshi Azuma (University of Tokyo) \\ Speakers: Tadahiko Inagaki (University of Tokyo) \\ Jun Hosya (Tohoku University) \\ Giyoo Hatano (Dokkyo University) \\ Akihiro Yoshida (Ochanomizu University)
}

In order to promote a contribution of educational psychology to instructional methodology, major goal of facilitating scientific communication between researchers was expected to be achieved.

Four speakers offered different viewpoints. Expectation of and request for educational psychology was the theme for discussion offered by Prof. T. Inagaki. Prof. J. Hosoya discussed "how we theorize the teaching and leaning processes" by showing examples of his own teaching programs based on his researches. From scientific research point of view, Prof. G. Hatano emphasized the important rigorous type of laboratory research in psychology, under the title of "The utility of laboratory 